Research Square

\title{
A robust speaker recognition based on Data augmentation
}

\section{Research}

Keywords:

Posted Date: December 2nd, 2020

DOI: https://doi.org/10.21203/rs.3.rs-16425/v2

License: (c) (i) This work is licensed under a Creative Commons Attribution 4.0 International License.

Read Full License 


\section{Abstract}

The authors have requested that this preprint be withdrawn due to erroneous posting.

\section{Full Text}

The authors have withdrawn this preprint from Research Square. 